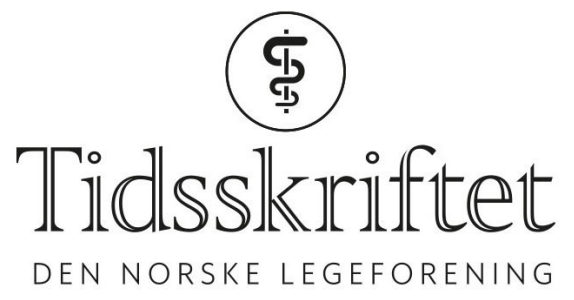

\title{
Bosted bestemmer behandling
}

LEDER

VIBEKE JULIEB Ø

E-post:v.juliebo@gmail.com

Vibeke Juliebø er ph.d., spesialist i indremedisin og i hjertesykdommer og er invasiv kardiolog ved PCI-senteret, Avdeling for hjertesykdommer, Akershus universitetssykehus. Forfatteren har fylt ut ICMJE-skjemaet og oppgir ingen interessekonflikter.

Bedre etterlevelse av vedtatte retningslinjer kan utjevne regionale forskjeller i behandlingen av pasienter med hjerteinfarkt.

I 2018 fikk over 13 ooo pasienter diagnostisert hjerteinfarkt i norske sykehus (1). Forekomsten har falt jevnt siden årtusenskiftet, og dødeligheten har blitt mer enn halvert i samme periode, men med en aldrende befolkning og store kull i etterkrigsgenerasjonen forventer man en $\emptyset$ kning i årene som kommer. Det er store regionale forskjeller i både forekomst og dødelighet. Finnmark, Hedmark og Oppland har en høyere aldersjustert dødelighetsrate grunnet hjerteinfarkt enn landsgjennomsnittet, mens Agder-fylkene har en lavere aldersjustert dødelighetsrate.

ST-elevasjonsinfarkt skyldes en okkludert koronararterie og behandles med revaskularisering i form av primær perkutan koronar intervensjon (PCI) eller en kombinasjon av trombolyse og PCI. De europeiske retningslinjene for ST-elevasjonsinfarkt fra 2017, som Norsk cardiologisk selskap har gitt sin tilslutning til, anbefaler revaskularisering til alle pasienter med ST-elevasjonsinfarkt og mindre enn 12 timers sykehistorie (2). PCI er den foretrukne formen for revaskularisering, men trombolytisk behandling bør vurderes dersom tid fra diagnose til PCI forventes å være over 120 minutter. I 2017 ble anbefalt tid fra diagnose til trombolytisk behandling redusert fra 30 minutter til 10 minutter, og det presiseres at pasientene bør få denne behandlingen prehospitalt og deretter bli transportert direkte til et PCI-senter. Ved manglende effekt av trombolytisk behandling anbefales det at PCI utføres akutt, ved tilfredsstillende effekt innen 2-24 timer. Hos pasienter med lang sykehistorie (inntil 48 timer) bør PCI vurderes selv om pasienten ikke lenger har tegn til pågående iskemi. Mange bor langt fra et PCI-senter, og man er avhengig av gode behandlingsforløp og velfungerende logistikk for å kunne gi behandling i tide.

Man er avhengig av gode behandlingsforløp og velfungerende logistikk for å kunne gi behandling i tide

I studien som publiseres i dette nummer av Tidsskriftet, har Arnesen og medarbeidere sett på tid til reperfusjon hos pasienter med ST-elevasjonsinfarkt (3). Studien belyser en viktig utfordring: Mange pasienter får ikke revaskularisering i tide. Resultatene fra Trondheim er i samsvar med de offisielle tallene fra Norsk register for invasiv kardiologi og Norsk 
hjerteinfarktregister $(4,5)$. I 2018 fikk bare $67 \%$ av pasientene revaskularisering innen anbefalt tid. Ved 32 av landets 53 sykehus var det mindre god måloppnåelse når det gjaldt tid før behandling i akuttfasen. Hos pasienter med ST-elevasjonsinfarkt er dødeligheten høy hvis pasientene ikke får behandling i tide. Flere store, randomiserte studier som har sammenliknet trombolytisk behandling og PCI, har vist at PCI er den foretrukne metoden for revaskularisering med tanke på dødelighet, nye hjerteinfarkt og hjerneslag. De fleste studiene sammenlikner PCI med trombolyse alene, mens europeiske retningslinjer anbefaler en kombinert strategi med trombolytisk behandling i påvente av $\mathrm{PCI}$ (2).

De europeiske anbefalingene om først trombolytisk behandling og deretter direkte transport til PCI-senter understøttes av en fransk registerstudie fra 2019 (6). I denne studien finner man, i likhet med Arnesen og medarbeidere, at tid fra diagnose til primær PCI ofte overskrider de anbefalte tidsrammene.

Også blant pasienter med ikke-ST-elevasjonsinfarkt er det store regionale forskjeller i behandlingen $(5,7)$. I 2018 ble $74 \%$ av disse pasientene unders $ø$ kt med koronar angiografi. Bare $46 \%$ fikk utført koronar angiografi innen 24 timer, slik europeiske retningslinjer anbefaler, mens $63 \%$ ble unders $\varnothing$ kt innen 72 timer. For mange av pasientene med små hjerteinfarkt risikerer man verken liv eller betydelig skade på myokard ved å vente 72 timer på koronar angiografi, men den lange ventetiden medfører en unødig belastning.

Utfordringen til de regionale helseforetakene er å utjevne forskjellene. Velfungerende behandlingskjeder som sikrer befolkningen raskest mulig behandling i henhold til retningslinjene ved alle typer hjerteinfarkt, vil trolig kunne utjevne noen av de forskjellene som nå observeres i forekomst, behandling og dødelighet ved hjerteinfarkt $(1,2,5)$.

\section{LITTERATUR:}

1. Hjerte- og karsykdommer i Norge. Folkehelseinstituttet. https://www.fhi.no/nettpub/hin/ikke-smittsomme/Hjerte-kar/ Lest 22.10.2019.

2. Ibanez B, James S, Agewall S et al. 2017 ESC Guidelines for the management of acute myocardial infarction in patients presenting with ST-segment elevation. Kardiol Pol 2018; 76: 229-313. [PubMed][CrossRef]

3. Arnesen JS, Strøm KH, Bønaa KH et al. Behandling av hjerteinfarkt med ST-elevasjon - en observasjonsstudie. Tidsskr Nor Legeforen 2019; 139. doi: 10.4045/tidsskr.18.o928. [CrossRef]

4. Norsk hjerteinfarktregister. Årsrapport 2018.

https://www.kvalitetsregistre.no/sites/default/files/2_arsrapport_2018_hjerteinfarkt.pdf Lest 28.10.2019.

5. Norsk Register For Invasiv Kardiologi (NORIC). Årsrapport for 2018 med plan for forbedringstiltak. https://www.kvalitetsregistre.no/sites/default/files/6_arsrapport_2018_noric.pdf Lest 28.10.2019.

6. Danchin N, Popovic B, Puymirat E et al. Five-year outcomes following timely primary percutaneous intervention, late primary percutaneous intervention, or a pharmaco-invasive strategy in ST-segment elevation myocardial infarction: the FAST-MI programme. Eur Heart J 2019; doi: 10.1093/eurheartj/ehz665/5572227. [PubMed][CrossRef]

7. Roffi M, Patrono C, Collet JP et al. 2015 ESC Guidelines for the management of acute coronary syndromes in patients presenting without persistent ST-segment elevation: Task Force for the Management of Acute Coronary Syndromes in Patients Presenting without Persistent ST-Segment Elevation of the European Society of Cardiology (ESC). Eur Heart J 2016; 37: 267-315. [PubMed][CrossRef]

Publisert: 18. november 2019. Tidsskr Nor Legeforen. DOI: 10.4045/tidsskr.19.0677

C Tidsskrift for Den norske legeforening 2020. Lastet ned fra tidsskriftet.no 